\title{
BIOLOGICAL CONTROL OF TOMATO WILT FUSARIUM UNDER PLASTIC-HOUSE CONDITIONS
}

(Received:12. 1. 2015

\author{
By \\ N. S. Al-Ameiri \\ Department of Plant Protection and IPM, Faculty of Agriculture, Mutah University, Karak, Jordan
}

\begin{abstract}
Tomato (Lycopersicon esculentum Mill.) is considered as one of the most important vegetable crops in the world and Jordan. Fusarium wilt of tomato, caused by Fusarium oxysporum f. sp. lycopersici is one of the most prevalent serious diseases of tomato. The experiment was set up in a completely randomized design (CRD), in which six different treatments were used. Fresh and dry weights of shoot and root, plant heights, root colonization, disease severity, disease incidence and disease control percentage were recorded. Results indicated that there were no symptoms observed in the control plants treated with Trichoderma harzianum alone or in plants grown in un-inoculated soil (tap water treatment). F. oxysporum f. sp. lycopersici caused a significant decrease in plant growth of both shoot and root fresh weights. The decrease in fresh shoot weight caused by the pathogen was $44.0 \%$ and $45.8 \%$, respectively, as compared with using $T$. harzianum as spore suspension or mycelium. Inoculation with $T$. harzianum increased shoot and root fresh weights as compared with un-inoculated plants or plants treated with $F$. oxysporum f. sp. lycopersici treatment. T. harzianum also achieved a significant increase in plant height as compared with the control. Plants height significantly decreased with $F$. oxysporum f. sp. lycopersici treatment. The results also showed a reduction in both disease severity and incidence in the bio-control treatment as compared with the plants treated with $T$. harzianum mycelium and T. harzianum spore suspension. T. harzianum mycelium treatment has significantly increased colonization percentage than T. harzianum spore suspension treatment. Healthy plants increased with application of T. harzianum, and this percentage increased and reached $55 \%$ and $64 \%$ with spore and mycelium treatments, respectively.
\end{abstract}

Key words: Trichoderma harzianum, Fusarium oxysporum f. sp. Lycopersici, biological control, tomato wilt, tomato, Jordan.

\section{INTRODUCTION}

Tomato (Lycopersicon esculentum Mill.) is considered as one of the most important vegetables in the world (Rick, 1979). This economic crop is considered the second commonly grown vegetable in the world and the first one in Jordan for local consumption or exportation purposes. Jordan produced 419.230 thousand tons of tomato from a planted area of about 820,890 dunums (Agricultural Statistics, 2013). However, tomato is affected by several diseases, reflecting negative effect on plant growth and yield. Fusarium spp. are among the most important plant pathogens in the world. Out of these, pathogenic fungi especially the wilt caused by Fusarium remains to be a challenging task in terms of management (Agrios, 2000 and Srinon et al., 2006).
Fusarium oxysporum is responsible for wilt and cortical rot diseases of more than 100 economically important plants (Swift et al., 2002). Fusarium wilt of tomato caused by $F$. oxysporum [(Schlecht.) f. sp. lycopersici (Sacc.)] Snyder et Hansen is one of the most prevalent serious diseases of tomato (Reis et al., 2005 and Sudhamoy et al., 2009).

Currently, controlling this pathogen is mainly done by chemical control (fungicides), which creates serious health hazard to applicators as well as to consumers of the treated plants. In addition to target organism, pesticides also kill various beneficial organisms. Their toxic forms persist in the soil and contaminate the environment (Hayes and Laws, 1991). Thus, alternative control measures are needed. Biological control involves the use of beneficial microorganisms, such as specialized fungi and 
bacteria. Two of the major bio-control agents, which reduce soil borne diseases of various crops, include isolates of the bacterium fluorescent, Pseudomonas spp. and the fungus, Trichoderma spp. (Howell and Stipanovic, 1995).

Therefore, the objectives of the present work were set as an attempt to evaluate the relative bio-control efficiency of $T$. harzianum in controlling tomato wilt caused by $F$. oxysporum f. sp. lycopersici, and to investigate the effect of $T$. harzianum in plants grown in pots, and test the use of $T$. harzianum treatment to induce any like-disease symptoms or abnormalities in the plants under plastic house conditions.

\section{MATERIALS AND METHODS}

\subsection{Fungal isolation and purivication}

The fungus, $F$. oxysporum f. sp. lycopersici was isolated from infected tomato plants obtained from the Agricultural Research Station fields, Faculty of Agriculture, Mu'tah University. The fungus was identified on the basis of their culture, morphological and microscopic characteristics. To obtain the inoculums, stem sections of wilted plants were placed onto Potato Dextrose Agar (PDA) at $25 \pm 2^{\circ} \mathrm{C}$ in the incubator. The cfu of $F$. oxysporum f. sp. Lycopersici was obtained from the wash off the agar surface with sterile distilled water; and filtered through Whatman No.1 filter paper (Maidstone, England) and repeated three times, and washed to be free of nutrients before adding to the soil at $5 \times 10^{6}$ $\mathrm{cfu} / \mathrm{ml}$ concentration.

\subsection{Source of bio-agent and preparation}

Wild type of Jordanian isolate $T$. harzianum was isolated from rhizosphere soil of infected tomato roots. The isolate was identified according to Rifai (1969), and it was mutagenezed by Benomyl tolerant as described by Ahmad and Baker (1987) containing $10 \mu \mathrm{g}$ a.i. benomyl/ $\mathrm{ml}$. Spores' suspension was obtained from culture of the fungus grown on PDA, and the plates were harvested by flooding with a sterile distilled water. The resulting suspension was then strained through cheesecloth to remove mycelia fragments, spores collected and filtered through Whatman No.1 filter paper (Maidstone, England) repeated three times, and washed to be free of nutrients before adding to the soil at $5 \times 10^{8}$ spores $/ \mathrm{ml}$ (AlAmeiri, 2007).

T. harzianum mycelium obtained from a culture of the fungus were grown on PDB. The medium was autoclaved, then cooled, seeded with $0.5 \mathrm{~cm}$ of $T$. harzianum disc, and incubated at shaking incubator for seven days. The culture was then strained through cheesecloth to remove mycelia fragments, the obtained mycelium was filtered through filter paper, repeated three times, and washed to be free of nutrients before adding to the soil (Al-Ameiri, 2007).

\subsection{Plastic house experiment}

\subsubsection{The effect of Trichoderma harzianum and $F$. oxysporum f. sp. Lycopersici on tomato growth}

Two week old tomato seedlings cv. GS12 averaging $5 \mathrm{~cm}$ in height were grown in a plastic house at the Agricultural Research Station, Faculty of Agriculture, Mu'tah University, and used in the experiment.

Plastic pots $(30 \times 25 \mathrm{~cm})$ were separately filled with $5 \mathrm{~kg}$ of sterilized soil. GS12 (cv) susceptible to Fusarium wilt was used in the experiment; in which five tomato seedlings were planted in each pot. The pots were placed on a plastic house bench, where the temperature was $27 \pm 5^{\circ} \mathrm{C}$. Two weeks post planting, each pot was inoculated with $60 \mathrm{ml} /$ pot of $F$. oxysporum $f$. sp. lycopersici $\left(5 \times 10^{6} \mathrm{cfu} / \mathrm{ml}\right)$ into $3 \mathrm{~cm}$ deep furrows, uniformly round sides of the seedlings. The pathogen inoculums were applied after this period to avoid developing damping-off of the seedling. At the time of pathogen inoculation either T. harzianum ( $50 \mathrm{ml}$ of spore suspension) with a final concentration of $5 \times 10^{8}$ spores $/ \mathrm{ml}$ or mycelium (5 $\mathrm{gm} / \mathrm{kg}$ of soil) were equally distributed around the seedlings in the respective treatments.

The experiment was set up in a completely randomized design (CRD), and conducted at the Agricultural Research Station, Faculty of Agriculture, Mu'tah University, in which each treatment consisted of three replicates (pots), with five plants/pot and the experiment was repeated twice. The treatments employed in the experiment were: (1) un-inoculated seedlings (drenched with tap water); (2) F. oxysporum f. sp. lycopersici only; (3) T. harzianum (spore suspension); (4) T. harzianum (mycelium) (5g kg of soil); (5) F. oxysporum f. sp. lycopersici + T. harzianum (spore suspension); and (6) F. oxysporum f. sp. lycopersici $+T$. harzianum (mycelium).

The plants were carefully watered by hand daily, and fertilized with a soluble feed plantNPK (12-10-12) at 10-day-interval after the antagonist-pathogen inoculation. After four weeks, the plants were exposed to water stress to 
enhance the development of $F$. oxysporum in the vascular system and produce the symptoms of wilt.

\subsubsection{The effect of Trichoderma harzianum on disease incidence and severity caused by $F$. oxysporum f. sp. lycopersici}

The bio-control activity was measured by the incidence of wilt produced by the pathogen on the treated plants upon appearance of $>20 \%$ disease symptoms on the pathogen treatment. Disease was monitored for 7 to 8 weeks and assayed as the total percentage of seedlings (disease incidence) showing any wilt symptoms resulted from the pathogen (i.e. yellowing and dropping of leaves, vascular discoloration wilting). Stem sections of wilted seedlings were surface-disinfested in $0.5 \%$ sodium hypochlorite then washed with a sterile distilled water and plated on PDA to confirm the presence of the $F$. oxysporum f. sp. lycopersici.

The disease severity of the pathogen infection on the plants was individually assessed at the end of the experimental time. A rating scale of 0 to 5 was used after modifying the scale of Grattidge and O'Brien (1982); where: 0: healthy plants; 1: $<24 \%$ of the leaves yellowed and wilted; $2: 25-49 \%$ of the leaves yellowed and wilted; 3: $50-74 \%$ of the leaves yellowed and wilted; 4: 75-99\% of leaves yellowed and wilted; and 5: 100\% the dead plants. The percentage of disease severity was calculated using the following scheme:

$$
\begin{aligned}
\text { Disease severity } \%= & \frac{\text { Sum of the rating value }}{}=\frac{\text { Total no. of plant/ replicate }}{\times 5 \text { (highest rating value) }}
\end{aligned}
$$

At harvesting time, the plants were collected and fresh and dry weights of shoots and roots were recorded. In addition, the colonization of $F$. oxysporum and $T$. harzianum fungus in the vascular system was determined by plating 25 segments of plant roots (5/plate), surface sterilized by immersing the root pieces in $1 \%$ sodium hypochlorite solution for $5 \mathrm{~min}$, and then washed several times in a sterilized distilled water to remove any residues of sodium hypochlorite. The segments of plant roots were plated on PDA plates using the method described by El-Hassan and Gowen (2006). After 7 days, the number of segments that produced $F$. oxysporum and $T$. harzianum colonies of each plant/plate was counted using a microscope. The competitive colonization percentage $(\%)$ was calculated as follows:
$\mathrm{CI}=$ [number of root segments colonized by bio-control agent or $F$. oxysporum/total number of root segments] $\mathrm{x}$ 100. Where: $\mathrm{CI}=$ Colonization index.

The efficiency of endophytic T. harzianum (disease percentage control) was presented as a reduction percentage in colonized vascular tissues by $F$. oxysporum. The disease percentage control was calculated according to Abbot (1925) formula:

$\begin{gathered}\text { Disease index of control (pathogen) }- \\ \text { Disease index of treatment }\end{gathered}$
\%Disease control=
Disease index of control (pathogen)

\subsection{Statistical Analysis}

Data obtained were statistically analyzed using MSTAT-C statistical package, disease severity, $F$. oxysporum and $T$. harzianum colonization percentage were transformed to $\sqrt{x+1}$ to reduce heterogeneity of variances and to overcome zero readings (Steel and Torrie, 1960). Analysis of variance was determined using Least Significant Differences (LSD) test for means separation. The level of significance was calculated at a probability level of 0.05 (Clewer and Scarisbrick, 2001).

\section{RESULTS}

\subsection{The effect of Trichoderma harzianum and $F$. oxysporum f. sp. lycopersici on tomato growth}

There were no symptoms observed in the control plants treated with $T$. harzianum alone or in the plants grown in un-inoculated soil (tap water treatment). The pathogen was not isolated from tomato vascular tissues of those treatments. The perusal of data presented in Fig. (1: A and B) clearly shows that $F$. oxysporum $f$. $s p$. lycopersici causes a significant decrease in plant growth of both shoot and root fresh weights. The decrease in fresh shoot weight caused by the pathogen was $44.0 \%$ and $45.8 \%$, respectively as compared with used $T$. harzianum as spore suspension and mycelium, respectively. A significant decrease (33\%) in shoot fresh weight was found between pathogen and uninculated treatments.

Single inoculations of T. harzianum increased shoot and root fresh weights as compared to the un-inoculated treatment and $F$. oxysporum f. sp. lycopersici treatment. Shoot dry weight was significantly affected by all treatments rather than $F$. oxysporum f. sp. lycopersic treatment (Fig. 1). There were no significant differences 


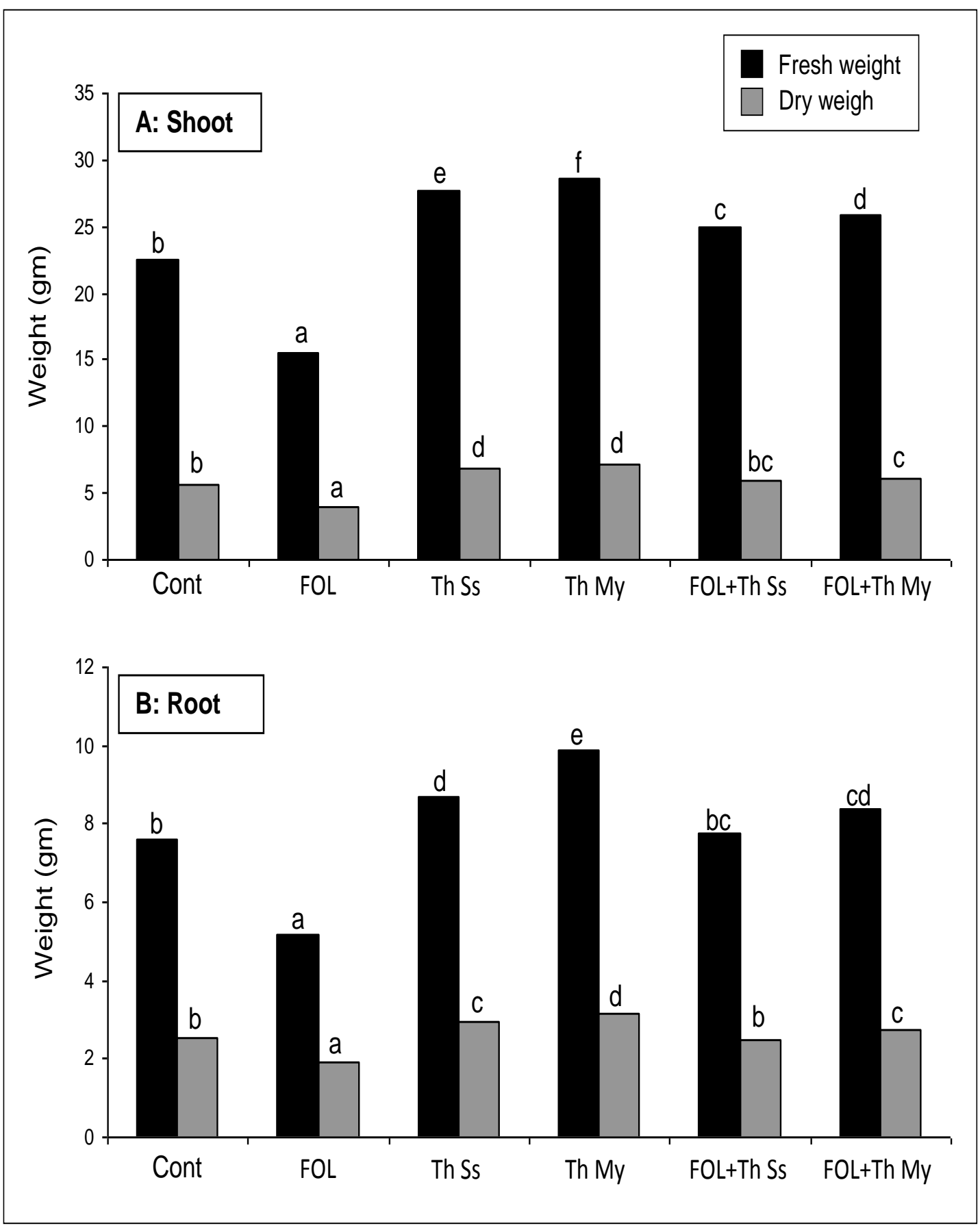

Fig. (1): Effects of Fusarium oxysporum f.sp. lycopersici and Trichoderma harzianum (spore suspension and mycelium) on shoot fresh and dry weights (A) root fresh and dry weights $(B)$ of tomato. *Where: 1- $($ Cont $)=$ control, 2- $($ FOL $)=F$. oxysporum f.sp. lycopersici, 3- $($ Th Ss $)=T$. harzianum Conidia suspension, $4-($ Th My $)=T$. harzianum Mycelium, 5- $($ FOL + Th Ss $)=F$. oxysporum $f$. sp. lycopersici, $+T$. harzianum Conidia suspension, $6-(\mathrm{FOL}+\mathrm{Th}$ My $)=F$. oxysporum f.sp. lycopersici, $+T$. harzianum Mycelium. **Different small letters above bars indicated significant differences among the five different treatments at $p<0.05$ (one-factor analysis of variance).

between application methods of $T$. harzianum when applied with or without $F$. oxysporum $\mathrm{f}$. sp. lycopersic. Root dry weight showed significant differences between $F$. oxysporum $\mathrm{f}$. sp. lycopersic and all treatments, either a significant differences between the two applications of $T$. harzianum with or without of F. oxysporum f. sp. lycopersic. 
In the potted culture under plastic-house conditions, $T$. harzianum only applied into pot soil caused a high significant increase in plant height as compared to the control treatment (Fig. 2). The method of applying antagonist had a significant effect between the two. T. harzianum mycelium treatment, and it has increased plant height than $T$. harzianum spore suspension treatment with or without $F$. oxysporum f. sp. lycopersic. Plant height significantly decreased in $F$. oxysporum f. sp. lycopersic treatment compared with all the treatments used. between the $T$. harzianum treatments, where $T$. harzianum mycelium treatment significantly reduced disease severity than $T$. harzianum spore suspension treatment.

The colonization percentage of root segments was not significantly different between the method of applied antagonist when the pathogen was absent. It was found that only T. harzianum spore suspension treatment with $F$. oxysporum $\mathrm{f}$. sp. lycopersici present decreased significantly colonization percentage compared with the other treatments. F. oxysporum f. sp. lycopersici added

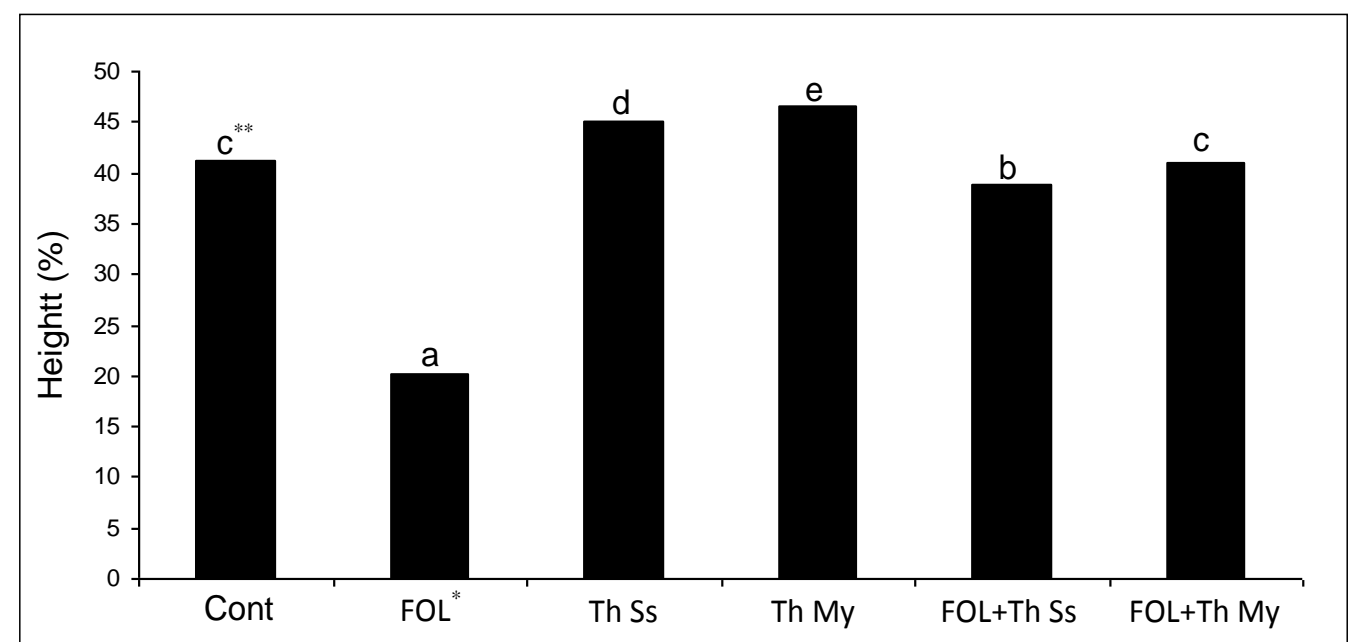

Fig. (2): Effects of $F$. oxysporum f.sp. lycopersici and Trichoderma harzianum (spore suspension and mycelium) on tomato heights. *Where: 1- (Cont) = control, 2- ( FOL) $=F$. oxysporum $f$. sp. lycopersici, 3- $(\mathrm{Th} \mathrm{Ss})=T$. harzianum Conidia suspension, 4 $($ Th $\mathrm{My})=\mathrm{T}$. harzianum Mycelium,-,5- $(\mathrm{FOL}+\mathrm{Th}$ Ss $)=F$. oxysporum $f$. sp. lycopersici,+ T. harzianum Conidia suspension, $6-($ FOL + Th My $)=F$. oxysporum $f$. sp. lycopersici $+T$. harzianum Mycelium. **Different small letters above bars indicated significant differences among the five different treatments at $p<0.05$ (onefactor analysis of variance).

\subsection{The effect of Trichoderma harzianum on disease incidence and severity caused by F. oxysporum f. sp. lycopersici}

The antagonist colonization percentage was developed as a general assessment of the ability of $T$. harzianum to establish an endophytic relationship with tomato plants in an attempt to protect the plants directly from the initial $F$. oxysporum f. sp. lycopersic infection. Isolating T. harzianum from vascular tissues indicated that the isolate was living inside the plant tissues and it is, therefore, an endophyte of tomato root (Fig. 3 ). The results clearly show a reduction in disease severity in the bio-control treatment as compared with the pathogen treatment (Fig. 4). Disease severity was significantly differed to the soil had significantly higher colonization of root segments than the treatments that have both of pathogen and bio-control. T. harzianum mycelium treatment significantly increased colonization percentage than $T$. harzianum spore suspension treatment.

Bio-control agent tested significantly reduced Fusarium wilt of tomato plants (Table 1). Disease control percentage increased with application of two types of T. harzianum. This percentage was highly increased and reached $55 \%$ and $64 \%$ with $T$. harzianum spore suspension and mycelium treatments, respectively. 


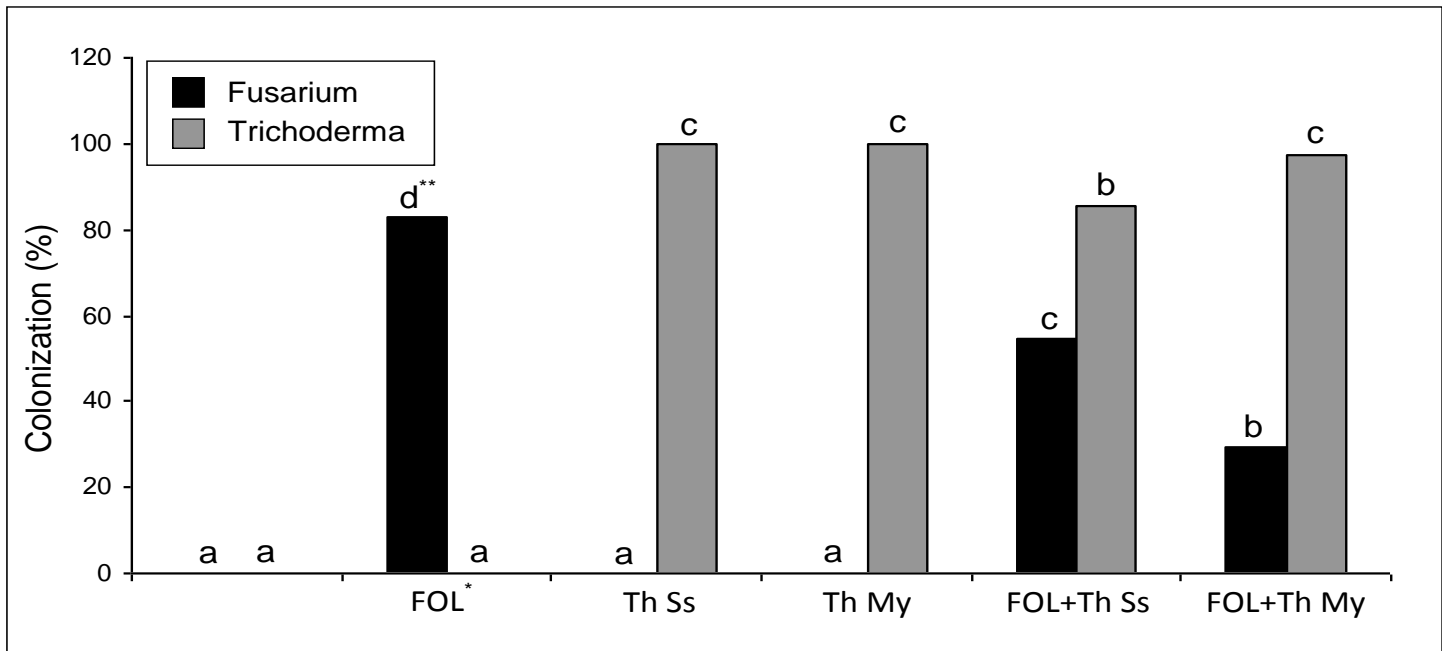

Fig. (3): Percent colonization of roots tomato plant by $F$. oxysporum $f$.sp. lycopersici and Trichoderma harzianum (spore suspension and mycelium) * Where: 1- $($ Cont $)=$ control, 2- $($ FOL $)=F$. oxysporum $f$. sp. Lycopersici, 3- $(\mathrm{Th} \mathrm{Ss})=T$. harzianum Conidia suspension, 4 - $($ Th My) $=T$. harzianum Mycelium, -, 5- $($ FOL+Th Ss $)=F$. oxysporum $f$. sp. lycopersici $+T$. harzianum Conidia suspension, $6-(\mathrm{FOL}+\mathrm{Th} \mathrm{My})=\mathrm{F}$. oxysporum $f$. sp. Lycopersici $+T$. harzianum Mycelium **Different small letters above bars indicated significant differences among the five different treatments at $p<0.05$. (one-factor analysis of variance).

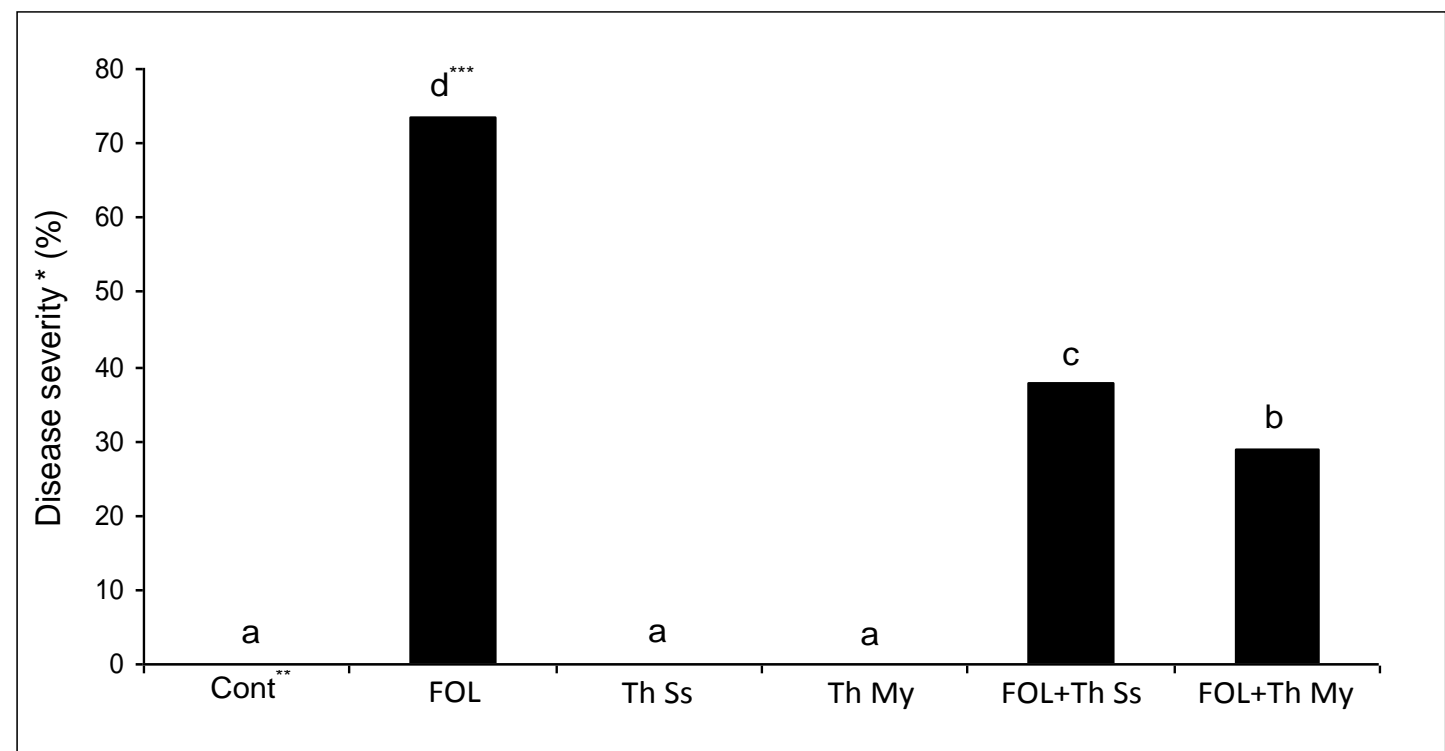

Fig. (4): Effect of Trichoderma harzianum (spore suspension and mycelium) on disease severity\% caused by $F$. oxysporum $f$. sp. lycopersici on tomato. * Disease severity was based on a scale (0-5) where: 0 , (healthy plant; $1,(>24 \%)$ of leaves yellowed and wilted; 2, (25$49 \%$ ) of leaves yellowed and wilted; 3, (50-74\%) of leaves yellowed and wilted; 4, (7599\%) of leaves yellowed and wilted; 5, (100\%) dead plan ** Where: 1 - $($ Cont $)=$ control, 2- $(\mathrm{FOL})=$ F. oxysporum $f$. sp. Lycopersici 3- $(\mathrm{Th} \mathrm{Ss})=T$. harzianum Conidia suspension, $4-($ Th My $)=$ T. harzianum Mycelium, - 5- $($ FOL+Th Ss) $=$ F. oxysporum $f$. sp. lycopersici $+T$. harzianum Conidia suspension, $6-($ FOL+Th My) $=F$. oxysporum $f$. sp. lycopersici $+T$. harzianum Mycelium. ***Different small letters above bars indicated significant differences among the five different treatments at $p<0.05$ (one-factor analysis of variance). 
Table (1): Disease incidence of tomato wilt Fusarium as affected by Trichoderma harzianum treatments.

\begin{tabular}{|c|c|c|}
\hline Treatments & Wilt (\%)* & Reduction (\%) \\
\hline Un-inoculated seedlings(control) & 0.0 d & 100 \\
\hline F. oxysporum f. sp. lycopersici only & $80 \mathbf{a}$ & $\mathbf{0 . 0}$ \\
\hline T. harzianum spore suspension & 0.0 d & 100 \\
\hline T. harzianum mycelium & $0.0 \mathrm{~d}$ & 100 \\
\hline F. oxysporum f. sp. lycopersici $+T$. harzianum (spore suspension) & $36 \mathbf{b}$ & 55 \\
\hline F. oxysporum f. sp. lycopersici $+T$. harzianum (mycelium) & 29 c & 64 \\
\hline
\end{tabular}

*Values followed by different letters within a column differ significantly $<0.05$.

\section{DISCUSSION}

The results of the current study indicated that under plastichouse conditions all methods of $T$. harzianum application whether single or in combination with $F$. oxysporum f. sp. lycopersic caused a significant increase in shoot and root fresh and dry weights as compared with the uninoculated control and $F$. oxysporum f. sp. Lycopersici (Fig. 1, A and B). In addition, there was a significant difference in plant height in all T. harzianum treatments (Fig. 2). The general mechanism of biological control can be divided into direct and indirect effects of the bio-control agent (BCA) on the plant pathogen. Direct effects include competition for nutrients or space, production of antibiotic and lytic enzymes, inactivation of the pathogen's enzymes and parasitism. Indirect effects include all those aspects that produce morphological and biochemical changes in the host plant, such as tolerance to stress through enhanced root and plant development, solubilization or sequestration of inorganic nutrients, and induced resistance (Viterbo et al., 2002). The rhizodeposition of the plants influences the surrounding soil and its microflora (Garbeva et al., 2011). The use of the bio-agent also results in an increase in shoot dry weight in steamed; this means that the bio-agent is able to increase plant height and weight through protection from infection with the pathogens (Mohamed and Abo-Raya, 1993; Adm, 2000; Al-Ameiri, 2007). These results are in agreement with those of Morsy et al. (2009), who found that the dual inoculation by $T$. viride and $F$. solani gave the highest records of growth parameters.

Various species of Trichoderma have received the most attention. Trichoderma harzianum is a fungal bio-agent that attacks a range of phytopathogenic fungi. T. harzianum alone or in combination with other Trichoderma species can be used in biological control of several plant diseases (Papavizas, 1985; Amini and Siddovich, 2010 and Al-Amreiri, 2014). It has been also reported to be effective in controlling Fusarium crown and root rot under greenhouse and field conditions (Meraj-Ul and Nandkar, 2012).

When the two fungi were co-inoculated, both were observed on the root. The presence of one of them on the root did not prevent its colonization by the other fungus. The amount of root colonization by $T$. harzianum was reduced with the two methods of application when the soil was infested with $F$. oxysporum f. sp. lycopersic. This reduction in colonization is consistent with a reciprocal competitive interaction for nutrients. Similar results were also reported by Olivain et al. (2006), who found that when strains of Fusarium oxysporum pathogenic and non pathogenic were introduced together, they both colonized the root surface and were observed at the same locations and this occurred for nutrients rather than for infection sites.

The ability of Trichoderma to protect plants against root pathogens has long been attributed to an antagonistic effect against the invasive pathogen (Chet et al., 1997). However, these root-fungus' associations also stimulate plant defensive mechanisms. Data presented in Figure (4) reveal that soil infested with $F$. oxysporum $\mathrm{f}$. sp. lycopersici significantly increased disease severity of tomato plants (75\%) more than those treated with $F$. oxysporum and $T$. harzianum spore suspension and mycelium treatments with only $40 \%$ and $35 \%$, respectively. However, the lowest percentage of disease severity of tomato plants was attained in response to treatment with T. harzianum. Similar results were reported by Getha et al. (2005), who observed that $T$. harzianum and $B$. subtilis were effective antagonists against $F$. oxysporum. Al-Ameiri (2014) found that $T$. harzianum decreased disease severity to $16 \%$ in mycelial preparation treatment as compared to Pythium aphanidermatum treatment, where it reached up to $73 \%$. Trichoderma strains are always associated with plant root and root ecosystems. Some authors have defined Trichoderma strains as plant symbiotic opportunistic virulent organisms, which are able to colonize plant 
roots by mechanisms similar to those of mycorrhizal fungi and to produce compounds that stimulate growth and plant defense mechanisms (Franken et al., 2002).

In conclusion, the current study demonstrated that the bio-agent, $T$. harzianum has the ability to suppress tomato wilt caused by $F$. oxysporum f. sp. lycopersici as indicated by reducing severity, incidence of disease and pathogen root colonization under plastic-house conditions, and increasing plant growth and no symptoms were observed in the control plants (T. harzianum alone).

\section{REFERENCES}

Abbot W. S. (1925). A method for computing the effectiveness of an insecticide. J. Econ. Entomol., 18: 265-267.

Adm K. A. (2000). Integrated control of seed, root rot and damping-off of tomato. Ph.D. Thesis, Faculty of Agriculture, Mosul University, Mosul, Iraq. 120 pp.

Agricultural Statistics. (2013). Department of Statistics, Amman, the Hashemite Kingdom of Jordan. $132 \mathrm{pp}$.

Agrios G. N. (2000). Significance of plant disease. Pp. 25-37, In: Agrios, G.N. (eds.), Plant Pathology. Academic Press, London, UK.

Al-Ameiri N. S. (2007). Biological control of cucumber damping-off caused by Pythium aphanidermatum. Bull. Fac. Agric., Cairo Univ., 58(3): 217-221.

Al-Ameiri N. S. (2014). Control of cucumber damping-off in the field by the bio-agent Trichoderma harzianum. Inter. J. Agric. Forest., 4(2): 112-117.

Ahmad J. S., and Baker R. (1987). Rhizosphere competence of Trichoderma harzianum. Phytopathology. 77:182-189.

Amini J. and Siddovich D. F. (2010). The effects of fungicides on Fusarium oxysporum $f$. sp lycopersici associated with fusarium wilt of tomato. J. Plant Protect. Res., 50 (2): 172-177.

Chet I., Inbar J. and Hadar I. (1997). Fungal antagonists and mycoparasites. In: Wicklow, D.T. and B. Söderström (eds.). The Mycota IV: Environmental and microbial relationships. Springer-Verlag, Berlin, Germany, pp 165-184.

Clewer A. G. and Scarisbrick D.H. (2001). Practical statistics and experimental design for plant and crop Science. John Wiley and Sons, Chichester. UK., 332 pp.
El-Hassan S. A. and Gowen S. R. (2006). Formulation and delivery of the bacterial antagonist Bacillus subtilis for management of lentil vascular wilt caused by Fusarium oxysporum $f$. sp. lentis. J. Phytopathol., 154(3): 148-155.

Franken P., Khun G., and Gianinazzi-Pearson V. (2002). Development and molecular biology of arbuscular mycorrhizal fungi. In: Osiewacz, H.D. (eds.). Molecular biology of fungal development. Marcel Dekker, New York, USA. pp 325-348.

Garbeva P., Gera Hol W. H., Termorshuizen A.J., Kowalchuk G.A. and de Boer W. (2011). Fungistasis and general soil biostasis - a new synthesis. Soil Biol. Biochem., 43: 469-477.

Getha K., Vikineswary S, Wong W. H, Seki T., Ward A. and Goodfellow M. (2005). Evaluation of Streptomyces sp. for suppression of Fusarium wilt and rhizosphere colonization in pot grown banana plantlets. J. Microbiol. Biotech., 32(1): 24-32.

Grattidge R. O and Brien R.G. (1982). Occurrence of third race of Fusarium wilts of tomatoes in Queensland. Plant Dis., 66: 165-166.

Hayes W. J. and Laws E. R. (1991). Handbook of Pesticide Toxicology. Vol: 1, Academic Press Inc., India. 92 pp.

Howell C. R. and Stipanovic R. D. (1995). Mechanisms in the biocontrol of Rhizoctonia solani-induced cotton seedling disease by Gliocladium virens antibiosis. Phytopathol., 85: 469-472.

Meraj-Ul H. and Nandkar P. B. (2012). Antagonistic effect of rhizospheric Trichoderma isolates against tomato damping-off pathogen Fusarium oxysporum $f$. sp. lycopersici. Int,. J. Res. Bio Sci., 2: 27-31.

Mohamed S. A. and Abo-Raya A. (1993). Biological control of tomato damping-off. Menofiya J. Agric. Res., 18 (4): 21312140.

Morsy E. M., Abdel-Kawi K. A. and Khalil M. N. (2009). Efficiency of Trichoderma viride and Bacillus subtilis as biocontrol agents against Fusarium solani on tomato plants. Egypt. J. Phytopathol., 37 (1): 4757.

Olivain C., Humbert C., Nahalkova J., Fatehi J., L'Haridon F. and Alabouvette C. (2006). Colonization of tomato root by pathogenic 
and nonpathogenic Fusarium oxysporum strains inoculated together and separately into the soil. Appl. Environ. Microbiol., 72 (2): 1523-1531.

Papavizas G. C. (1985). Trichoderma and Gliocladium: biology, ecology, and potential for biocontrol. Ann. Rev. Phytopathol., 23: 23-54.

Reis A., Costa H., Boiteux L. S. and Lopes C.A. (2005). First report of Fusarium oxysporum f. sp. lycopersici race 3 on tomato in Brazil. Fitopatologia Brasileira 30: 426-428.

Rick C. M. (1979). The biology and taxonomy of the Solanaceae. pp. 667-677, In: Biosystematic studies in Lycopersicon and closely related species of Solanum.

Rifai M. A. (1969). A revision of the genus Trichoderma. Myco. Papers Imp. Mycol. Inst., 116, 1.

Srinon W., Chuncheen K., Jirattiwarutkul K., Soytong K. and Kanokmedhakul S.
(2006). Efficacies of antagonistic fungi against Fusarium wilt disease of cucumber and tomato and the assay of its enzyme activity. J. Agric. Tech., 2(2): 191-201.

Steel R. G. and Torie J. H. (1960). Principles and procedures of Statistics. McGrawHill, New York.

Sudhamoy M., Nitupama M. and Adinpunya M. (2009). Salicylic acid induced resistance to Fusarium oxysporum f. sp. Lycopersici in tomao. Plant Physiol. Biochem., 47: 642-649.

Swift C. E., Wickiffe E. R. and Schwartz H. F. (2002). Vegetative compatibility groups of Fusarium oxysporum $f$. sp. cepae from onion in Colorado. Plant Dis., 86: 606610.

Viterbo A., Ramot O., Chernin L. and Chet I. (2002). Significance of lytic enzymes from Trichoderma spp. in the biocontrol of fungal plant pathogens. Anton. Leeuw., 81: 549-556.

\title{
المكافحة الحيوية لمرض الأبول الفيوزارمي الأي يصيب الطماطم تحت ظروف البيوت البلاستيكية

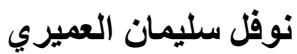

\section{قسم الوقاية والمكافحة المتكاملة_ كلية الزراعةـ جامعة مؤتةــ الكركـ الاردن}

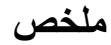

يعتبر نبات الطماطم من أهم نباتات الخضر إقتصاديا في العالم، وفي الاردن يحتل المرتبــة الاولى من ناحية

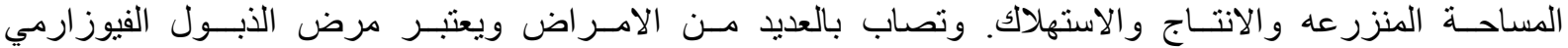
و المتسـبب عن الفطر Fusarium oxysporum f. sp. lycopersici من الامراض الهامه. أجريت تجربة بالتصميم العشوائي الكامل تحت ظروف الصوب البلاستيكية في محطة الربة الزراعية لكلية الزراعة/جامعة مؤتة. تم استخدام

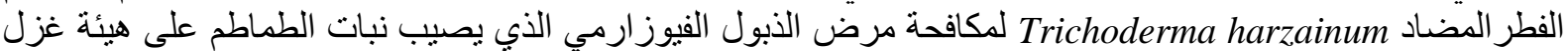

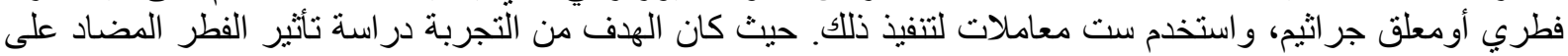

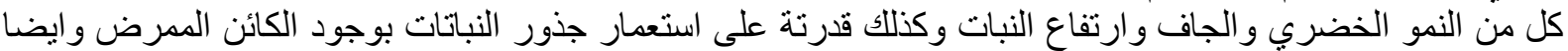

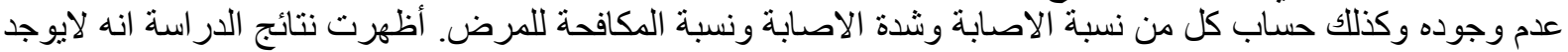

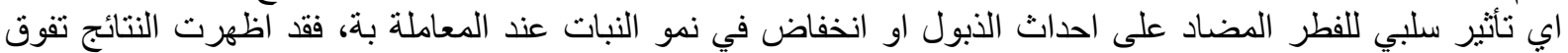

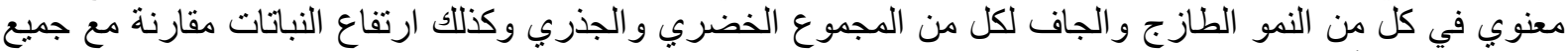

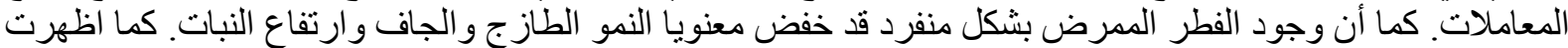

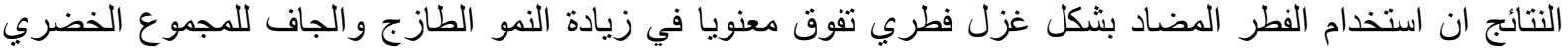

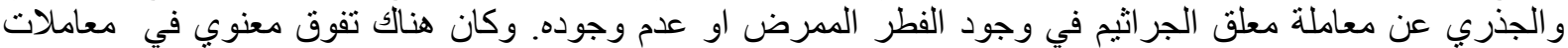

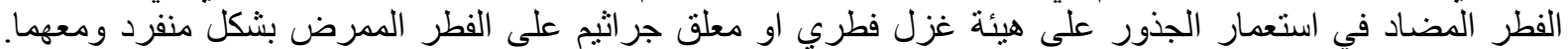
و أظهرت النتائج أن معاملة الفطر المضاد على هيئة غزل فطري تفوقت معنويا على معاملة معلق الجر اثئم في في استعمار

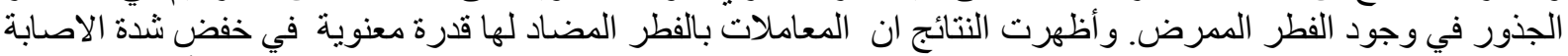

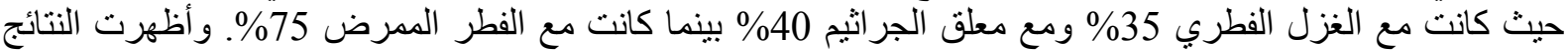

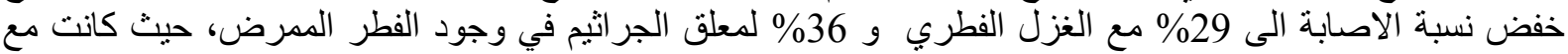
الفطر الممرض بمفرده 80\% و أدت المعاملات الى مكافحة المرض حهرضث حيث وصلت نسبة مكافحة المرض الى 64\% و54\% مع الغزل الفطري ومعلق الجر اثيم على التو الي.
\end{abstract}

